\title{
The Twin Peaks of Dante's Theology in the Paradiso
}

Né tra l'ultima notte e 'l primo die sì alto $\mathrm{o}$ sì magnifico processo, o per l'una o per l'altra, fu o fie: ché più largo fu Dio a dar sé stesso per far l'uom sufficiente a rilevarsi, che s'elli avesse sol da sé dimesso;

e tutti li altri modi erano scarsi a la giustizia, se 'l Figliuol di Dio non fosse umilïato ad incarnarsi.

Regnum celorum vïolenza pate da caldo amore e da viva speranza, che vince la divina volontate:

non a guisa che l'omo a l'om sobranza, ma vince lei perché vuole esser vinta, e, vinta, vince con sua beninanza.

(Par. VII.112-20 and XX.94-99) ${ }^{1}$

1. Introduction: preliminary emphases - being, affectivity and a reconfiguration of the theological issue. 2. Atonement theology I: Anselm and the Christ event as a matter of reparation. 3. Atonement theology II: Dante and the Christ event as a matter of re-potentiation. 4. Election theology I: Thomas, implicit faith and salvation in casu. 5. Election theology II: Dante, explicit faith and the love-susceptibility of the Godhead.

Dante's is a love-interpretation of existence under the conditions of time and eternity. Everything that is in the world as an object of perception

\footnotetext{
${ }^{1}$ Nor between the last night and the first day has there been or will there be so exalted and so magnificent a procedure, either by one or the other; for God was more bounteous in giving himself to make man sufficient to uplift himself again, than if he solely of himself had remitted; and all other modes were scanty in respect to justice, if the Son of God had not humbled himself to become incarnate ... Regnum celorum suffers violence from fervent love and from living hope which vanquishes the divine will; not as man overcomes man, but vanquishes it because it wills to be vanquished, and, vanquished, vanquishes with its own benignity.
} 
and delight stands to be understood in terms $(a)$ of its proceeding from the Godhead as original and abiding love, and $(b)$ of its tending from deep within itself - from out of the love given with the act itself of existence towards its proper perfection in the world. Eloquent in respect of the first of these things, of the notion of God as original and abiding love and as forever opening out in fresh channels of creative and recreative concern, is the 'Non per aver a sé di bene acquisto' passage of Par. XXIX.13-18, an essay in the twofold love-immanence and love-extrinsication of the One who is as of the essence:

Non per aver a sé di bene acquisto, ch'esser non può, ma perché suo splendore potesse, risplendendo, dir "Subsisto", in sua etternità di tempo fore, fuor d'ogne altro comprender, come i piacque, s'aperse in nuovi amor l'etterno amore. ${ }^{2}$

while no less committed in respect of the second of them, of the notion of everything as tending from out of its connatural affectivity towards a consummate act of existence, is this passage from the Convivio (III.iii.2-5), an essay in being in general as but the sum total of its love-impulses:

Onde è da sapere che ciascuna cosa, come detto è di sopra, per la ragione di sopra mostrata ha 'l suo speziale amore. Come le corpora simplici hanno amore naturato in sé a lo luogo proprio, e però la terra sempre discende al centro; lo fuoco ha [amore a] la circunferenza di sopra, lungo lo cielo de la luna, e però sempre sale a quello. Le corpora composte prima, sì come sono le minere, hanno amore a lo luogo dove la loro generazione è ordinata, e in quello crescono e acquistano vigore e potenza; onde vedemo la calamita sempre da la parte de la sua generazione ricevere vertù. Le piante, che sono prima animate, hanno amore a certo luogo più manifestamente, secondo che la complessione richiede; e però vedemo certe piante lungo l'acque quasi c[ontent]arsi, e certe sopra li gioghi de le montagne, e certe ne le piagge e dappiè monti: le quali se si transmutano, o muoiono del tutto o vivono quasi triste, sì come cose disgiunte dal loro amico. $\mathrm{Li}$ animali bruti hanno più manifesto amore non solamente a li luoghi, ma l'uno l'altro vedemo amare. Li uomini hanno loro proprio amore a le perfette e oneste cose. E però che l'uomo, avvegna che una sola sustanza sia, tuttavia [la] forma, per la sua nobilitade, ha in sé e la

2 Not for gain of good unto himself, which cannot be, but that his splendour might, in resplendence, say "Subsisto" - in his eternity beyond time, beyond every other bound, as it pleased him, the eternal love opened into new loves. 
natura [d'ognuna di] queste cose, tutti questi amori puote avere e tutti li ha. ${ }^{3}$

Thus everything that is in the world, be it animate or inanimate, is open to contemplation in terms of the affective economy of the whole, of being as, again, no more than the aggregate of its love-instances. And it is this sense of existence both severally and in the round as open to interpretation in terms of the love by which it is moved from deep within itself that determines the form and content of two of the great doctrinal emphases of the Commedia: in the area of atonement theology, its commitment to the notion of God's initiative in Christ as a matter of moral and ontological empowerment, as that whereby man as man is once again made sufficient on the planes of being and doing (the 'per far l'uom sufficiente a rilevarsi' moment of Par. VII.116); ${ }^{4}$ and, in the area of election theology, its sense of the love-susceptibility of it all, of God's willingness to be overcome, not only by the justified in Christ, but by all those living out the synderectic substance of their humanity (the 'ma vince lei perché vuole esser vinta' moment of Par. XX.98). ${ }^{5}$ Now neither of these things need scandalize the pious spirit, those sensitive $(a)$ to the nature of grace as, always and everywhere, the condition of human being and becoming, and (b) to God's immunity to anything but the substance of his own intentionality, for each of them survives intact within the soteriological economy of the whole. But in surviving intact they are relieved of any sense $(a)$ of the continuing poverty of the human situation in respect of its

${ }^{3}$ It is important to know, therefore, that, as was said above and for the reason adduced there, everything has its own special kind of love. Just as simple bodies have an inborn love for the place proper to them - so that earth always descends to the centre, while fire has an inborn love for the circumference above us bordering the heaven of the Moon, and therefore always rises upwards towards that - so primary compound bodies, such as minerals, have a love for the place suited to their generation; in that place they grow, and from it they derive their vigour and power. That is why, as we observe, the magnet always receives power from the quarter in which it was generated. Plants, which are the primary form of animate life, even more clearly have a love for certain places, in accordance with what their constitution requires; and so we see that some plants rejoice, as it were, when alongside water, others when on the ridges of mountains, others when on slopes and on foothills; if they are transplanted, they either die completely or live a sad life, like beings so to speak separated from their friends. Brute animals not only more clearly still have a love for particular places, but, as we observe, they also love one another. Human beings have their specific love, for what is perfect and just. And since the human being, despite the fact that his whole form constitutes a single substance in virtue of its nobility, has a nature that embraces all these features, he can have all these loves, and indeed does have them.

${ }^{4}$ [for God was more bounteous in giving himself] to make man sufficient to uplift himself again [than if he solely of himself had remitted].

${ }^{5}$ but vanquishes it because it wills to be vanquished ... 
power to significant determination, and (b) of the inevitable reprobation of those through no fault of their own a stranger to Christ. On the contrary, they testify between them to something more magnanimous and more magnificent than this, to a sense on Dante's part of the kind of loveencompassing whereby the human project may be said both to subsist in its intrinsic viability, and to commend itself in the sight of God as its author and architect.

2. Quite apart from the solutions it advances in the area of salvation theology, the Cur Deus bomo of Anselm commended itself in Dante's time as the classic case of theology under the aspect of faith seeking understanding (fides quaerens intellectum), for what is going on here is a proposal of the faith component of the religious life in terms of its reasonableness, of its making good sense. ${ }^{6}$ Without prejudice to the mystery of it all, the theologian seeks to throw light on the contents of faith as belief, to gloss the bow and why of God's purposes under the aspect of their intelligibility. Anselm, availing himself of the obvious text here (I Peter 3:15), puts it thus:

Saepe et studiosissime a multis rogatus sum et verbis et litteris, quatenus cuiusdam de fide nostra quaestionis rationes, quas soleo respondere quaerentibus, memoriae scribendo commendem. Dicunt enim eas sibi placere et arbitrantur satisfacere. Quod petunt, non ut per rationem ad fidem accedant, sed ut eorum quae credunt intellectu et contemplatione delectentur, et ut sint, quantum possunt, 'parati semper ad safisfactionem omni poscenti se rationem de ea quae in nobis est spe'.

(Cur Deus bomo I.i prin. $)^{7}$

${ }^{6}$ K. Barth, Fides quaerens intellectum. Anselm's Proof of the Existence of God in the Context of bis Theological Scheme (Pittsburg, Pickwick Press, 1985; originally 1960). More generally on the soteriological issue in Christian theology, R. S. Franks, The Work of Christ. A Historical Study of Christian Doctrine (London and New York: Nelson, 1962); F. W. Dillistone, The Christian Understanding of Atonement (Philadelphia: Westminster Press, 1968); A. McGrath, Iustitia Dei. A History of the Christian Doctrine of Justification. The Beginnings to the Reformation (Cambridge: Cambridge University Press, 1986); R. Cessario, The Godly Image: Christ and Salvation in Catholic Thought from Anselm to Aquinas (Petersham, MA: St Bede's Publications, 1990); J. McIntyre, The Shape of Soteriology (Edinburgh: T. \& T. Clark, 1992). Older but still serviceable, H. Rashdall, The Idea of Atonement in Christian Theology (London: MacMillan, 1925; originally 1919); G. Aulén, Christus Victor. An Historical Study of the Three Main Types of the Idea of Atonement, trans. A. G. Hebert (New York: Macmillan, 1951).

7 I have often been asked most earnestly, both by word of mouth and in writing, by many people, to set down a written record of the reasoned explanations with which I am in the habit of answering people who put enquiries to me about a certain position in our faith. For they say that these explanations please them, and they think them satisfactory. They make this request, not with a view to arriving at faith through reason, but in order 
His, therefore, in the Cur Deus bomo, is an epoche or parenthesizing of every given in respect of the Christ and of the Christ event in favour of its logicality, of its acceptibility even to the most sceptical of spirits:

Quod secundum materiam de qua editum est, Cur Jeus homo nominavi et in duos libellos distinxi. Quorum prior quidem infidelium Christianam fidem, quia rationi putant illam repugnare, respuentium continet obiectiones et fidelium responsiones. Ac tandem remoto Christo, quasi numquam aliquid fuerit de illo, probat rationibus necessariis esse impossibile ullum hominem salvari sine

that they may take delight in the understanding and contemplation of the things which they believe, and may be, as far as they are able, "ready to give satisfaction to all who ask the reason for the hope that is in us [1 Peter 3:15]". The Latin text is F. S. Schmitt (ed.), Anselmi Opera Omnia, 6 vols (Edinburgh: Nelson, 1946-61), in facsimile in S. Anselmi Cantuariensis archiepiscopi opera omnia ad fidem codicum recensuit Franciscus Salesius Schmitt, 6 vols in 2 (Stuttgart: F. Frommann, 1968-84). It may also be consulted in Migne, $P L$ CLVIII, 360C-432B. There are several translations, this one (from Schmitt, 1946) by J. Fairweather in Anselm of Canterbury. The Major Works, ed. B. Davies and G. R. Evans (Oxford: Oxford University Press, 1998), pp. 260-356 (slightly amended). On the Cur Deus homo (but the list is selective), J. McIntyre, St Anselm and bis Critics: A Re-Interpretation of the Cur Deus Homo (Edinburgh and London: Oliver and Boyd, 1954); G. H. Williams, Anselm: Communion and Atonement (Saint Louis: Concordia, 1960); C. B. Gray, 'Freedom and Necessity in St Anselm's Cur Deus bomo', Franciscan Studies 14 (1976-77), 177-91; G. R. Evans, 'Cur deus bomo: the Nature of St Anselm's Appeal to Reason', Studia Theologica 31 (1977), 33-50; B. Leftow, 'Anselm on the Beauty of the Incarnation', The Modern Schoolman 72 (1995), 109-24; idem, 'Anselm on the Necessity of the Incarnation', Religious Studies 31 (1995), 167-85; R. Campbell, 'The Conceptual Roots of Anselm's Soteriology', in D. E. Luscombe and G. R. Evans (eds), Anselm: Aosta, Bec and Canterbury. Papers in Commemoration of the Nine-hundreth Anniversary of Anselm's Enthronement as Archbishop, 25 September 1093 (Sheffield: Sheffield Academic Press, 1996), pp. 256-63. More generally on Anselm, R. W. Southern, St Anselm and His Biographer: a Study of Monastic Life and Thought, 1059-c.1130 (Cambridge: Cambridge University Press, 1963); idem, St Anselm: A Portrait in a Landscape (Cambridge: Cambridge University Press, 1990); J. R. Fortin (ed.), Saint Anselm: Hiw Origins and Influence (Lewiston, N.Y.: E. Mellen Press, 2001); G. R. Evans, Anselm (London: Continuum, 2002; originally 1989); B. Davies and B. Leftow (eds), The Cambridge Companion to Anselm (Cambridge: Cambridge University Press, 2004). On Dante and Anselm, in addition to C. Ryan, 'Marking the Difference between Dante and Anselm', in Dante and the Middle Ages, ed. J. Barnes and C. Ó Cuilleanáin (Dublin: Irish Academic Press, 1995), pp. 117-37 (a piece to which I am much indebted in the first part of this essay), and to commentaries and lecturae on Paradiso VII generally (see especially G. Fallani, 'Il Canto VII del Paradiso', in Paradiso: Letture degli anni 1979. 81, ed. S. Zennaro (Rome: Bonacci, 1989), pp. 233-39), A. Agresti, Dante e S. Anselmo (Naples: de Bonis, 1887); F. S. Schmitt, ad voc. 'Anselmo' in the Enciclopedia dantesca, 6 vols (Rome: Istituto dell'Enciclopedia Italiana, 1970-78), vol. 1, pp. 293-94; G. Muresu, 'Le "vie" della redenzione (Paradiso VII)', Rassegna della letteratura italiana, eighth series, 98 (1994), 1-2, 5-19 (subsequently in Il richiamo dell'antica strega (Rome: Bulzoni, 1997), pp. 203-24); R. McMahon, Understanding the Medieval Meditative Ascent. Augustine, Anselm, Boethius, and Dante (Washington, D.C., The Catholic University of America Press, 2006). 
illo. In secundo autem libro similiter quasi nihil sciatur de Christo, monstratur non minus aperta ratione et veritate naturam humanam ad hoc institutam esse, ut aliquando immortalitate beata totus homo, id est in corpore et anima, fruereter; ac necesse esse ut hoc fiat de homine propter quod factus est, sed non nisi per hominem-deum; atque ex necessitate omnia quae de Christo credimus fieri oportere.

(Cur Deus bomo, praefatio $)^{8}$

Setting aside, then, all we have come to believe about the Christ as made known to us by revelation, we may begin by saying that man as man was created to live in a state of covenantal bliss, in the kind of happiness contingent upon his acknowledging himself as a child of the Most High. But in the moment of his disobedience, of his grasping at equality with God, reparation fell due, reparation not only equal to that disobedience but, in defiance of mere proportionality, exceeding it:

Hoc est debitum quod debet angelus et homo deo, quod solvendo nullus peccat, et quod omnis qui non solvit peccat. Haec est iustitia sive rectitudo voluntatis, quae iustos facit sive rectos corde id est voluntate. Hic est solus et totus honor, quem debemus deo et a nobis exigit deus. Sola namque talis voluntas opera facit placita deo, cum potest operari; et cum non potest, ipsa sola per se placet, quia nullum opus sine illa placet. Hunc honorem debitum qui deo non reddit, aufert deo quod suum est, et deum exhonorat; et hoc est peccare. Quamdiu autem non solvit quod rapuit, manet in culpa. Nec sufficit solummodo reddere quod ablatum est, sed pro contumelia illata plus debet reddere quam abstulit. Sicut enim qui laedit salutem alterius, non sufficit si salutem restituit, nisi pro illata doloris iniuria recompenset aliquid: ita qui honorem alicuius violat non sufficit honorem reddere, si non secundum exhonorationis factam molestiam aliquid, quod placeat illi quem exhonoravit, restituit. Hoc quoque

${ }^{8}$ I have named it, in consideration of its subject-matter, Why God became man, and have divided it into two books. The first book contains the objections of unbelievers who reject the Christian faith because they think it militates against reason, and the answers given by the faithful. And eventually it proves, by unavoidable logical steps, that, supposing Christ were left out of the case, as if there had never existed anything to do with him, it is impossible that, without him, any member of the human race could be saved. In the second book, similarly, the supposition is made that, even knowing nothing of Christ, it is open to demonstration with no less clear logic and truth: that human nature was instituted with the specific aim that at some stage the whole human should enjoy blessed immortality, 'whole' meaning 'with both body and soul'; that it was inevitable that the outcome concerning mankind which was the reason behind man's creation should become a reality, but that this could only happen through the agency of a Man-God; and that it is from necessity that all the things which we believe about Christ have come to pass. 
attendendum quia, cum aliquis quod iniuste abstulit solvit, hoc debet dare, quod ab illo non posset exigi, si alienum non rapuisset. Sic ergo debet omnis qui peccat, honorem deo quem rapuit solvere; et haec est 'satisfactió, quam omnis peccator deo debet facere.

(ibid. i.xi) ${ }^{9}$

- at which point, given the depth of man's destitution and his manifest inequality to the task in hand, the inevitability of God's work in Christ, of his stepping in to do what man could not do for himself, moves clearly into view. Now here we need to be careful, for in speaking of the necessity - by which we mean the logical necessity - of Christ's coming amongst us, we have to acknowledge its love-dimensionality, the referability of everything God set out to do in Christ to his mercy in man's regard; so, for example, as transparent to the substance of Anselmian piety, these lines from ii.20 on the compassion which is God, on the generosity which is Christ, and on these between them as the ground of hope in the midst of hopelessness:

Misericordiam vero Dei quae tibi perire videbatur, cum iustitiam dei et peccatum hominis considerabamus, tam magnam tamque concordem iustitiae invenimus, ut nec maior nec iustior cogitari possit. Nempe quid misericordius intelligi valet, quam cum peccatori tormentis aeternis damnato et unde se redimat non habenti deus pater dicit: accipe unigenitum meum et da pro te; et ipse filius: tolle me et redime te? Quasi enim hoc dicunt, quando nos ad Christianam fidem vocant et trahunt. ${ }^{10}$

9 This is the debt which man and angel owe to God, and no one who pays this debt commits sin; but every one who does not pay it sins. This is justice, or uprightness of will, which makes a being just or upright in heart, that is, in will; and this is the sole and complete debt of honour which we owe to God, and which God requires of us. For it is such a will only, when it can be exercised, that does works pleasing to God; and when this will cannot be exercised, it is pleasing of itself alone, since without it no work is acceptable. He who does not render this honour which is due to God, robs God of his own and dishonours him; and this is sin. Moreover, so long as he does not restore what he has taken away, he remains in fault; and it will not suffice merely to restore what has been taken away, but, considering the contempt offered, he ought to restore more than he took away. For as one who imperils another's safety does not enough by merely restoring his safety, without making some compensation for the anguish incurred, so he who violates another's honour does not enough by merely rendering honour again, but must, according to the extent of the injury done, make restoration in some way satisfactory to the person whom he has dishonoured. We must also observe that when any one pays what he has unjustly taken away, he ought to give something which could not have been demanded of him, had he not stolen what belonged to another. So then, every one who sins ought to pay back the honour of which he has robbed God; and this is the satisfaction which every sinner owes to God.

${ }^{10}$ Now, the mercy of God which, when we were considering the justice of God and the sin of mankind, seemed to you to be dead, we have found to be so great, and so consonant 
Implicit, therefore, in the Cur Deus homo, and here explicit, is Anselm's referral of the calculative aspect of the atonement to its compassionate aspect, to the movement of love by which it is inaugurated and maintained. But this, for the moment, is not what interests him, for what interests him is, again, the logic of the case, thoughts of compassion not only not entering into it, but tending to compromise the nature of the Godhead as original and abiding justice; so, for example, as a caveat to the ii. 20 passage noted above, the following lines from i.24, with their sense of God's brooking no excuse when it comes to exacting his due:

Quod si vis dicere: misericors Deus dimittit supplicanti quod debet, idcirco quia reddere nequit: non potest dici dimittere, nisi aut hoc quod homo sponte reddere debet nec potest, id est quod recompensari possit peccato, quod fieri non deberet pro conservatione omnis rei quae Deus non est; aut hoc quod puniendo ablaturus erat invito, sicut supra dixi, id est beatitudinem. Sed si dimittit quod sponte reddere debet homo, ideo quia reddere non potest, quid est aliud quam: dimittit Deus quod habere non potest? Sed derisio est, ut talis misericordia Deo attribuatur. At si dimittit quod invito erat ablaturus, propter impotentiam reddendi quod sponte reddere debet: relaxat Deus poenam et facit beatum hominem propter peccatum, quia habet quod debet non habere. Nam ipsam impotentiam debet non habere, et idcirco, quamdiu illam habet sine satisfactione, peccatum est illi. Verum huiusmodi misericordia Dei nimis est contraria iustitiae illius, quae non nisi poenam permittit reddi propter peccatum. Quapropter quemadmodum Deum sibi esse contrarium, ita hoc modo illum esse misericordem impossibile est. ${ }^{11}$

with justice, that a greater and juster mercy cannot be imagined. What, indeed, can be conceived of more merciful than that God the Father should say to a sinner condemned to eternal torments and lacking any means of redeeming himself, "Take my only-begotten Son and give him on your behalf", and that the Son himself should say, "Take me and redeem yourself"? For it is something of this sort that they say when they call us and draw us towards the Christian faith.

${ }^{11}$ But if you want to say, "A merciful God remits the debt of anyone who begs forgiveness on the ground that he is incapable of making repayment", God cannot be said to be remitting anything except either that which the person ought to repay and cannot, that is, recompense which he might hypothetically be able to give for his $\sin -\sin$ which ought not to be committed even for the sake of preserving everything that exists which is not God - or, alternatively, that which, by way of punishment, he was about to take away from a person against that person's will, that is, the state of blessed happiness. But if God remits what a person cannot give back of his own volition, for the reason that he is incapable of giving it back, how is this different from saying: "God remits what he is not able to have"? But it is mockery for mercy of this kind to be attributed to God. If, however, God remits what he was about to take away from a person against his will, because of that person's incapacity to make payment, in that case he is making his 
There can be no question then, Anselm insists, of God's giving up or going back here, for giving up and going back when it comes to good order makes a mockery of the whole thing, and God will suffer no mockery. And this, as an aspect of his setting aside every kind of faith-awareness in the Cur Deus bomo in favour of argumentation pure and simple, is a point he will not let go of; so, for example, in the same chapter, his statement to the effect that God is indeed a merciful God, but that, rather than the other way round, mercy follows upon justice as the dominant mode of God's dealings with man - at which point the good Boso, impressed (or maybe just oppressed) by the non-negotiability of it all, gives way:

B. Si rationem sequitur Deus iustitiae, non est qua evadat miser homuncio, et misericordia Dei perire videtur.

A. Rationem postulasti, rationem accipe. Misericordem Deum esse non nego, qui "homines et iumenta" salvat, "quemadmodum multiplicavit misericordiam suam" - Nos autem loquimur de illa ultima misericordia, qua post hanc vitam beatum facit hominem. Hanc beatitudinem nulli dari debere nisi illi, cui penitus dimissa sunt peccata, nec hanc dimissionem fieri nisi debito reddito, quod debetur pro peccato secundum magnitudinem peccati, supra positis rationibus puto me sufficienter ostendisse. Quibus si quid tibi videtur posse rationibus obici, dicere debes.

$B$. Ego utique nullam tuarum rationum aliquatenus infirmari posse video. ${ }^{12}$

Now this again, as an account of what is going on in the Cur Deus homo, needs careful statement, since for Anselm as for every seasoned Christian spirit what God does he does in and through the love co-terminous

punishment lax and making a person happy on account of his sin, in that the person has what he ought not to have. For his very incapacity is something he ought not to have, and therefore, so long as he has it without paying recompense, it is sin on his part. But mercy of this kind is absolutely contrary to God's justice, which does not allow anything to be given in repayment for sin except punishment. Hence, given that it is impossible for God to be self-contradictory, it is impossible for him to be merciful in this way.

${ }^{12} B$. If the God of justice acts according to logic, there is no route whereby man in his meanness may escape, and it seems that the mercy of God is dead.

$A$. You asked for logic, and so here it is. I do not deny that God is merciful, he who saves "men and beasts in accordance with how he has multiplied his mercy" [Ps. 36: 7-8; 35 iuxta LXX]. Moreover, we are talking about that final mercy, whereby, after this life, he makes a human being blessedly happy. That this state of bliss ought not to be given to anyone whose sins have not been utterly forgiven, and that this forgiveness ought not to happen except on repayment of a debt which is owed because of his sin and which is proportioned to the magnitude of his sin, I think I have demonstrated by the logical reasonings set out earlier. If it seems to you that any objection can be made to these logical reasonings, you ought to say so.

$B$. I see no way of showing your logical reasonings to be in the slightest invalid. 
and thus consubstantial with his being. To look elsewhere in his work, therefore, particularly among his prayers and meditations, is to register his sense both of the incarnation and of the crucifixion as a matter of boundless self-giving, at which point legality is taken up in love as the currency of all God's dealings with man in his far-offness. But - and this now is the point - love, by reason of Anselm's chosen methodology in the Cur Deus homo, is contemplated across its judicial aspect, the judicial aspect, he thinks, being both excisable from the salvific scheme generally and furnishing an object of contemplation in its own right. ${ }^{13}$

3. It is by way, then, of Anselm's sense of the cross as God's way of seeing that justice was done and his honour preserved intact that we come to Dante's sense of Christ's work on Calvary as a matter of moral and ontological re-potentiation, as that whereby, in and through the Word made flesh, man was re-empowered in respect of what he already was, and now is once more, as a creature of reasonable self-determination. The key canto is Canto VII of the Paradiso, Dante's being a step-by-step reconstruction of the argument until at last he settles on the notion of moral and ontological co-adequation as his point of arrival, of God's once again making man equal to the business in hand. First, then, comes the offence itself, his sense of Eden as a matter of wilfulness, of the unwillingness of our first parents to suffer the yoke of their creatureliness. ${ }^{14}$ In fact, the

${ }^{13}$ For a gentler view of the Cur Deus homo, a sense of the text as belonging to the mainstream of Anselmian piety, D. Brown in his 'Anselm on Atonement' in The Cambridge Companion to Anselm (note 7 above), pp. 279-302, at p. 290: 'He was no cold rationalist imposing purely external criteria on God but a devout monk concerned to explore his faith in a God, the internal logic of whose nature, he believed, entailed His never failing to act beautifully and well.' For a critique of the position in Anselm, ranging over both the strengths and the weaknesses of that position, A. Harnack, History of Dogma, seven volumes bound as four (unabridged republication of the English translation of the third German edn), trans. N. Buchanan (New York: Dover Publications, 1961), vol.6, p. 54 ff. More recently, J. McIntyre, Saint Anselm and His Critics: A Re-interpretation of the Cur Deus bomo (note 7 above).

${ }_{14}$ B. Nardi, 'Il concetto dell'impero nello svolgimento del pensiero dantesco', in Saggi difilosofia dantesca, 2nd edn (Florence: La Nuova Italia, 1967), pp. 215-75 (especially pp. 215-28); N. Borsellino, 'Notizie sull'Eden (Paradiso XXVI)', Lettere Italiane 41 (1989), 3, 321-33 (and in Sipario dantesco. Sei scenari della Commedia (Rome: Salerno, 1991), pp. 88101); L. Cardellino, 'Struttura del poema e senso del viaggio. Eden: peccato originale e umiltà', in Autocritica infernale (Milan: Jaca Book, 1992), pp. 25-51; C. A. Mangieri, 'L'Eden dantesco: allegorismo e significazione', in Italian Quarterly 41, 161-62 (2004), 5-53; W. W. Marshall, 'Dante and the Doctrine of Original sin. A Theological Gloss on Purgatorio XVI, 80-105 and Paradiso XXVII, 121-41', Dante. Rivista internazionale di studi su Dante Alighieri 3 (2006), 21-40. More generally, J. B. Kors, O.P., La Justice primitive et le peché originel J'après S. Thomas: Les sources, la doctrine, (Paris: Vrin, 1930; originally 1922); H. Rondet, Original Sin: the Patristic and Theological Background, trans. C. Finegan 
idea is already there in the twilight pages of the Purgatorio, where it is a question pre-eminently of melancholy and misgiving:

E una melodia dolce correva per l'aere luminoso; onde buon zelo mi fé riprender l'ardimento d'Eva,

che là dove ubidia la terra e 'l cielo, femmina, sola e pur testé formata, non sofferse di star sotto alcun velo;

sotto 'l qual se divota fosse stata, avrei quelle ineffabili delizie sentite prima e più lunga fiata.

(Purg. XXIX.22-30) ${ }^{15}$

But in the Paradiso melancholy and misgiving give way to something more drastic, to a sense of the co-implication of all men in the self-undoing of Adam:

Per non soffrire a la virtù che vole freno a suo prode, quell' uom che non nacque, dannando sé, dannò tutta sua prole.

$(\text { Par. VII.25-27) })^{16}$

It was in response to this situation, then, to Adam's guilt as visited upon the generations and as borne by them in an attitude of patient expectation (the 'molt' anni lacrimata pace' of Purg. X.35), ${ }^{17}$ that God looked to its resolution in Christ, to a descent into the flesh as the way of reconciliation:

onde l'umana specie inferma giacque giù per secoli molti in grande errore,

(Shannon, Eire: Ecclesia Press, 1972; originally Le Péché originel dans la tradition patristique et théologique (Paris: Fayard, 1967)); H. Köster, Urstand, Fall und Erbsünde in der Scholastik (Freiburg: Herder, 1979); R. Martorelli Vico,'La dottrina della giustizia originale e del peccato originale nel trattato De peccato originali di Egidio Romano', Documenti e Studi sulla Tradizione Filosofica Medievale 1 (1990), 1, 227-46; P. J. Weithman, 'Augustine and Aquinas on Original Sin and the Function of Political Authority', Journal of the History and Philosopby 30 (1992), 3, 353-76.

15 And a sweet melody ran through the luminous air; wherefore good zeal made me reprove Eve's daring, that, there where earth and heaven were obedient, a woman alone and but then formed, did not bear to remain under any veil, under which, if she had been devout, I should have tasted those ineffable delights before, and for a longer time.

${ }^{16}$ By not enduring for his own good a curb upon the power that wills, that man who was never born, in damning himself damned all his progeny.

17 the peace wept for since many a year ... 
fin ch'al Verbo di Dio discender piacque

u' la natura, che dal suo fattore

s'era allungata, unì a sé in persona

con l'atto sol del suo etterno amore.

(Par. VII.28-33) ${ }^{18}$

But - and this now is the question - why? Why this complicated way of going about it? Would not a suitable reprimand, perhaps with a penalty proportionate to what man as man could afford to pay, have been enough? To this, Dante is ready with a reply, but not before establishing the ground of that reply, namely its rootedness in love as nothing other than the endless working out of the Pentateuchal let it be, as that whereby whatever $i$ in the world as an object of perception and delight is confirmed from deep within itself in its equality to a consummate act of existence. The Christ event, in other words, necessary as it was and still is to man's homecoming as man, was necessary by virtue, not of the law, but of love, of the kind of love, which, in any adult understanding of what love is, functions as a principle of emancipation and, by way of emancipation, of actualization - the substance of the exquisite 'mature in the flame of love' tercet beginning at line 58 :

Questo decreto, frate, sta sepulto a li occhi di ciascuno il cui ingegno ne la framma d'amor non è adulto. ${ }^{19}$

Only now, on the basis of a developed sense of love as a matter of letting a thing be in the totality of that being, is it possible to see into the mystery of it all and to fashion from that mystery a moment of intelligibility. Dante, therefore, secure in the strength of his leading intuition, proceeds to its definitive statement, each successive emphasis serving to draw out and to develop the content of its predecessor. First, then, comes his sense of the Fall as forfeiture, as a foregoing of God's original gift to mankind: of the immortality whereby he himself would share in the sempiternity of the Godhead,,$^{20}$ of the freedom whereby he would be unconstrained by

18 wherefore the human race lay sick down there for many centuries in great error, until it pleased the word of God to descend where he, by the sole act of his eternal love, united with himself in person the nature which had estranged itself from its maker.

19 This decree, brother, is buried from the eyes of everyone whose understanding is not mature in the flame of love. L. M. La Favia, Soteriologia e poesia (Par. VII). Giustizia e amore (Ravenna: Centro Dantesco dei Frati Minori Conventuali, 2011).

${ }^{20}$ Anselm, Cur Deus homo ii.2: 'Quod autem talis factus sit, ut necessitate non moreretur, hinc facile probatur, quia, ut iam diximus, sapientiae et iustitiae Dei repugnat, ut cogeret hominem mortem pati sine culpa, quem iustum fecit ad aeternam beatitudinem. Sequitur 
anything other than his own righteousness, ${ }^{21}$ and of these things between them as the substance and meaning of his God-likeness, of his subsisting in the image of his maker. ${ }^{22}$ To forfeit any one of them, Dante thinks, is to know self in the disenfranchisement and thus in the dysfunctionality of self, in the falling away of self from its own high calling:

La divina bontà, che da sé sperne ogne livore, ardendo in sé, sfavilla sì che dispiega le bellezze etterne.

Ciò che da lei sanza mezzo distilla non ha poi fine, perché non si move la sua imprenta quand' ella sigilla.

Ciò che da essa sanza mezzo piove libero è tutto, perché non soggiace a la virtute de le cose nove.

ergo, quia si nunquam peccasset nunquam moreretur'; ibid. ii.11: 'Non puto mortalitatem ad puram sed ad corruptam hominis naturam pertinere', etc. Thomas, ST Ia.97.1 resp.: 'Tertio modo dicitur aliquid incorruptibile ex parte causae efficientis. Et hoc modo homo in statu innocentiae fuisset incorruptibilis et immortalis. Quia, ut Augustinus dicit in libro de quaest. Vet. et Nov. Test., "Deus hominem fecit, qui quandiu non peccaret, immortalitate vigeret, ut ipse sibi auctor esset aut ad vitam aut ad mortem". Non enim corpus eius erat indissolubile per aliquem immortalitatis vigorem in eo existentem; sed inerat animae vis quaedam supernaturaliter divinitus data, per quam poterat corpus ab omni corruptione praeservare, quandiu ipsa Deo subiecta mansisset', etc. In Scripture, Ecclesiastes 3:14: 'Didici quod omnia opera, quae fecit Deus, perseverent in perpetuum', etc.

${ }^{21}$ Purg. XVI.79-81, but also, by way of the Dante-character's reply to Brunetto Latini's particular brand of astral determinism (Inf. XV.46-47; 55-57; 70-72), Inf. XV.88-96. Exact, in this sense, the commentary of Benvenuto da Imola ad loc.: 'Et addit aliam praerogativam, scilicet libertatis, dicens, repetendo eadem verba, ciò che piove da essa, idest, procedit ab eadem bonitate, senza mezzo, idest, organo coeli, è tutto libero, ab omni corruptione, ab omni coactione; et ecce rationem: perchè non soggiace alla virtude, scilicet informativae, delle cose nuove, scilicet planetarum et stellarum, quae de novo creatae sunt et non sunt $\mathrm{ab}$ aeterno. Et hic nota quod corpora coelestia influunt in terrestria et elementaria quantum ad distinctionem temporum et productionem generabilium et corruptibilium; non tamen influunt super liberum arbitrium per vim constellationum, quam quidam philosophi dixerunt factum, nec sunt certa signa futurorum contingentium, contra quae homo potest per liberum arbitrium ...'

${ }^{22}$ Mon. I.viii.2 (on the in-breathing of Godlikeness), Par. V.19-24 (with Mon. I.xii.6, on free will as the principle in man of Godlikeness). Thomas on the threefold modality of man's assimilation to God, ST Ia.93.4 resp.: 'imago Dei tripliciter potest considerari in homine. Uno quidem modo, secundum quod homo habet aptitudinem naturalem ad intelligendum et amandum Deum; et haec aptitudo consistit in ipsa natura mentis, quae est communis omnibus hominibus. Alio modo, secundum quod homo actu vel habitu Deum cognoscit et amat, sed tamen imperfecte; et haec est imago per conformitatem gratiae. Tertio modo, secundum quod homo Deum actu cognoscit et amat perfecte; et sic attenditur imago secundum similitudinem gloriae.' 
Più l'è conforme, e però più le piace;

ché l'ardor santo ch'ogne cosa raggia, ne la più somigliante è più vivace.

Di tutte queste dote s'avvantaggia

l'umana creatura, e s'una manca, di sua nobilità convien che caggia.

(ibid., 64-78) ${ }^{23}$

The situation, then, is bleak, man as man, in the wake of Eden, knowing himself only in the powerlessness of sin (the 'solo il peccato è quel che la disfranca' of line 79), ${ }^{24}$ in the dissimilitude or God-unlikeness of the guilty spirit (the 'falla dissimile al sommo bene' of line 80), ${ }^{25}$ in the darkling spirituality of the offender (the 'per che del lume suo poco s'imbianca' of line 81), ${ }^{26}$ in the indignity of being in its remotion (the 'in sua dignità mai non rivene' of line 82$),{ }^{27}$ and in the moral emptiness of it all (the 'se non rïempie, dove colpa vòta' of line 83$)^{28}$ - bleakness shading off in these circumstances into impossibility, into a delivery of self to the near-nothingness of self. This at any rate is the meaning of the 'Ficca mo l'occhio per entro l'abisso' sequence beginning at line 94, where the notion of impasse ushers in that of a fresh initiative from on high, of an auxilium Dei designed to do for man what he cannot do for himself:

Ficca mo l'occhio per entro l'abisso de l'etterno consiglio, quanto puoi al mio parlar distrettamente fisso.

Non potea l'uomo ne' termini suoi mai sodisfar, per non potere ir giuso con umiltate obedïendo poi,

quanto disobediendo intese ir suso; e questa è la cagion per che l'uom fue

${ }^{23}$ The divine goodness, which spurns all envy from itself, burning within itself so sparkles that it displays the eternal beauties. That which immediately derives from it thereafter has no end, because when it seals, its imprint may never be removed. That which rains down from it immediately is wholly free, because it is not subject to the power of new things. It is the most conformed to it and therefore pleases it the most; for the holy ardour, which irradiates everything, is most living in what is most like itself. With all these gifts the human creature is advantaged, and if one fails, it needs must fall from its nobility.

${ }^{24}$ Sin alone is that which disfranchises it ...

${ }^{25}$ and makes it unlike the supreme good ...

${ }^{26}$ so that it is little illumined by its light.

${ }^{27}$ and to its dignity it never returns ...

${ }^{28}$ unless, where fault has emptied, it is filled afresh [with just penalties against evil delight]. 
da poter sodisfar per sé dischiuso.

Dunque a Dio convenia con le vie sue riparar l'omo a sua intera vita, dico con l'una, o ver con amendue. ${ }^{29}$

God, then, alone equal to the task in hand, had just two options: either to wipe the slate clean and start all over again, or to leave man to sort it out for himself (the 'o che Dio solo per sua cortesia / dimesso avesse, o che l'uom per sé isso / avesse sodisfatto a sua follia' of lines 91-93)? ${ }^{30}$ In the event he chose neither. Or, rather, he chose both, both to forgive with a suitable penalty (the penalty paid by Christ in his suffering as man for

${ }^{29}$ Fix your eyes now within the abyss of the eternal counsel, as closely focused on my words as you are able. Man, within his own limits, could never make satisfaction, for not being able to descend in humility, by subsequent obedience, so far as in his disobedience he had intended to ascend; and this is the reason why man was shut off from power to make satisfaction by himself. Therefore it was needful for God, with his own ways, to restore man to his full life - I mean with one way, or else with both.

30 either that God alone, solely by his clemency, had pardoned; or that man should of himself have given satisfaction for his folly. Thomas on the impossibility of God's having forgiven man without satisfaction, ST IIIa.46.2 ad 3: 'Alioquin, si voluisset absque omni satisfactione hominem a peccato liberare, contra iustitiam non fecisset. Ille enim iudex non potest, salva iustitia, culpam sive poenam dimittere, qui habet punire culpam in alium commissam, puta vel in alium hominem, vel in totam rempublicam, sive in superiorem principem. Sed Deus non habet aliquem superiorem, sed ipse est supremum et commune bonum totius universi. Et ideo, si dimittat peccatum, quod habet rationem culpae ex eo quod contra ipsum committitur, nulli facit iniuriam, sicut quicumque homo remittit offensam in se commissam absque satisfactione, misericorditer, et non iniuste agit.' It was for various reasons more fitting that God should have proceeded in quite the way he did in Christ, for (a) Christ's passion shows forth God's love for man, (b) it provides a model of submission and humility, $(c)$ it merits for man justifying grace and ultimate glory, $(\partial)$ it binds him more strongly to obedience, and (e) it confirms him in his moral dignity (ibid. IIIa.46.3 resp.). On the depth, and thus the impossibility, of man's depravity in consequence of Eden (for the 'Non potea l'uomo ne' termini suoi' passage beginning at VII.97), Hugh of St Victor, De verbi incarn. viii: 'Ad hanc plenitudinem oportuit, ut tanta esset humiliatio in expiatione, quanta fuerit praesumptio in praevaricatione. Rationalis autem substantiae Deus tenet summum, homo vero imum gradum. Quando ergo homo praesumpsit contra Deum, facta est elatio de imo ad summum. Oportuit ergo, ut ad expiationis remedium fieret humiliatio de summo ad imum; Thomas, ST IIIa.1.2 ad 2: 'Hominis puri satisfactio sufficiens esse non potuit pro peccato, tum quia tota humana natura erat per peccatum corrupta; nec bonum alicujus personae, vel etiam plurium, poterat per aequiparantiam totius naturae detrimentum recompensare; tum etiam qui peccatum contra Deum commissum quamdam infinitatem habet ex infinitate divinae majestatis; tanto enim offensa est gravior, quanto major est ille in quem delinquitur. Unde oportuit ad condignam satisfactionem ut actus satisfacientis haberet efficaciam infinitam, utpote Dei et hominis existens', etc. For the 'per sé isso' component of the formula, Thomas, ST Ia IIae.109.7 resp.: 'homo nullo modo potest resurgere a peccato per seipsum sine auxilio gratiae'; IIa IIae.164.2 resp.: 'Et quia ad illum statum primae innocentiae per seipsum redire non poterat', etc. 
man) and, by identifying with him in the midst of his desolation, to make it possible for him to participate in his own renewal. This, then, is the substance of the 'Ma perché l'ovra tanto è più gradita' moment of Canto VII beginning at line 106, a passage tending in its sense of God's work in Christ as a matter of love-empowerment to fashion from atonement theology an essay, not so much in sacrifice, as in sufficiency, in the newly won adequacy of man to his proper destiny:

Ma perché l'ovra tanto è più gradita da l'operante, quanto più appresenta de la bontà del core ond' ell' è uscita,

la divina bontà che 'l mondo imprenta, di proceder per tutte le sue vie, a rilevarvi suso, fu contenta.

Né tra l'ultima notte e 'l primo die sì alto $o$ sì magnifico processo, o per l'una o per l'altra, fu o fie:

ché più largo fu Dio a dar sé stesso per far l'uom sufficiente a rilevarsi, che s'elli avesse sol da sé dimesso;

e tutti li altri modi erano scarsi a la giustizia, se 'l Figliuol di Dio non fosse umilïato ad incarnarsi. ${ }^{31}$

Now here too we must be careful, for just as Anselm's account in the Cur Deus bomo of God's work in Christ as a matter of his exacting his due is enfolded at last by a sense of the love-dimensionality of it all, so Dante takes seriously its judicial component, the notion of a debt to be redeemed and of an account to be settled. Twice, then, in the course of Paradiso VII he lights on the retributive or legalistic aspect of the argument, its quid pro quo aspect (the 'nulla già mai sì giustamente morse' moment of line 42 and the 'tutti li altri modi erano scarsi / a la giustizia, se 'l Figliuol di Dio / non fosse umilïato ad incarnarsi' moment of lines 118-20), ${ }^{32}$ Anselm, in this sense, never being far away. But for all that, the differences are greater

${ }^{31}$ But because the deed is so much the more prized by the doer, the more it displays of the goodness of the heart whence it issued, the divine goodness which puts its imprint on the world, was pleased to proceed by all its ways to raise you up again; nor between the last night and the first day has there been or will there be so exalted and so magnificent a procedure, either by the one or by the other; for God was more bounteous in giving himself to make man sufficient to uplift himself again, than if he solely of himself had remitted; and all other modes were scanty in respect to justice, if the Son of God had not humbled himself to become incarnate.

${ }^{32}$ none ever so justly stung ... and all other modes were scanty in respect to justice, if the Son of God had not humbled himself to become incarnate. 
than the similarities; for this is a thinking through of the Christ event in terms, not of logic, but of love, not of the apologetic, but of the agapeic. It is a meditation turning upon the notion, not so much of debt and the paying off of debt, as upon the endless love-outpouring of the Godhead as that whereby man knows himself in the fullness of his humanity, at which point atonement theology, like every other species of theology in Dante, is drawn at last into the ambit of creation theology, of a theology both moved by and transparent to God's original and abiding concern for the human project in the viability of that project.

4. But that is not all, for this sense of love as a matter of letting it be and of this as a key to understanding in the area of salvation theology, extends also into the area of election theology, where as our control text we may take, not Anselm, but Aquinas, the Aquinas of the De veritate and of the Summa theologiae. Aquinas's, then, though not without qualification, is a proposal of this issue in terms of explicit faith, of a positive profession of the Christ as the condition in man of ultimate homecoming. In the Summa theologiae the matter arises in the course of the faith articles of the Secunda secundae, where in reply to the question as to whether a man is bound to believe anything explicitly ('utrum homo teneatur ad credendum aliquid explicite'), Thomas affirms that whereas the contingencies of the scriptural narrative need not compel in conscience, the leading propositions of the faith are binding for the purposes of salvation:

Determinatio igitur virtuosi actus ad proprium et per se obiectum virtutis est sub necessitate praecepti, sicut et ipse virtutis actus. Sed determinatio actus virtuosi ad ea quae accidentaliter vel secundario se habent ad proprium et per se virtutis obiectum non cadit sub necessitate praecepti nisi pro loco et tempore. Dicendum est ergo quod fidei obiectum per se est id per quod homo beatus efficitur, ut supra dictum est. Per accidens autem vel secundario se habent ad obiectum fidei omnia quae in Scriptura divinitus tradita continentur, sicut quod Abraham habuit duos filios, quod David fuit filius Isai, et alia huiusmodi. Quantum ergo ad prima credibilia, quae sunt articuli fidei, tenetur homo explicite credere, sicut et tenetur habere fidem.

(ST IIa IIae.2.5 resp.) ${ }^{33}$

33 Accordingly, just as a virtuous act is required for the fulfilment of a precept, so is it necessary that the virtuous act should terminate in its proper and direct object: but, on the other hand, the fulfilment of the precept does not require that a virtuous act should terminate in those things which have an accidental or secondary relation to the proper and direct object of that virtue, except in certain places and at certain times. We must, therefore, say that the direct object of faith is that whereby man is made one of the blessed, as stated above [qu. 1, art. 8]; while the indirect and secondary object comprises 
Attentive, therefore, to the distinction between what does and does not matter, or, more exactly, between what matters primarily and what matters secondarily, the text settles on a sense of explicit faith in the primary articles of religion as the ground of man's ultimate well-being. And what applies in the Secunda secundae at 2.5 applies in Articles 7 and 8 of the same question in relation to the mysteries of the incarnation and of the Trinity, where it is a question of faith as consent to the hypostatic union of the human and the divine in Christ and to the triune substance of the Godhead as the ground of salvation:

illud proprie et per se pertinet ad obiectum fidei per quod homo beatitudinem consequitur. Via autem hominibus veniendi ad beatitudinem est mysterium incarnationis et passionis Christi, dicitur enim Act. IV, 'non est aliud nomen datum hominibus in quo oporteat nos salvos fieri'. Et ideo mysterium incarnationis Christi aliqualiter oportuit omni tempore esse creditum apud omnes ... mysterium Christi explicite credi non potest sine fide Trinitatis, quia in mysterio Christi hoc continetur quod filius Dei carnem assumpserit, quod per gratiam spiritus sancti mundum renovaverit, et iterum quod de spiritu sancto conceptus fuerit.

(ST IIa IIae.2.7 resp. and 8 resp. $)^{34}$

Thomas's, then, is a commitment to the notion of explicit faith as a principle of homecoming, formal profession of the Christian mysteries entering as of the essence into the salvific economy of the whole. But for all their consistency at this point, these articles of the Secunda secundae register a caveat, for in well-nigh the same breath Thomas acknowledges the notion of implicit faith as a means of salvation among two groups of people: (a) the Jewish inferiores or those living within the Old Law but

all things delivered by God to us in Holy Writ, for instance that Abraham had two sons, that David was the son of Jesse, and so forth. Therefore, as regards the primary points or articles of faith, man is bound to believe them, just as he is bound to have faith. Here, as elsewhere, in this essay, I am much indebted to the work of the late professor Christopher Ryan in his Dante and Aquinas. A Study of Nature and Grace in the Comedy, a text revised and edited by me on the basis of papers kindly made available by his widow and soon to be published.

${ }^{34}$ the object of faith includes, properly and directly, that thing through which man obtains beatitude. Now the mystery of Christ's incarnation and passion is the way by which men obtain beatitude; for it is written in Acts 4 [v. 12] that "there is no name under heaven given to men, whereby we must be saved". Therefore belief of some kind in the mystery of Christ's incarnation was necessary at all times and for all persons ... it is impossible to believe explicitly in the mystery of Christ, without faith in the Trinity, since the mystery of Christ includes that the Son of God took flesh, that he renewed the world through the grace of the Holy Ghost, and again that he was conceived by the Holy Ghost. 
not learned in it, and (b) those who, knowing neither the Old nor the New Law, may nonetheless be said to have an inkling of the providentiality of it all and maybe even of their ultimate deliverance. Notable as far as the first of these groups is concerned, the Jewish inferiores, are the following lines from the Secunda secundae at 2.7 resp. and 2.8 resp. with their sense that, while in respect of the Christ now among us, an act of explicit faith is required both of the inferiores and of the superiores, in respect of the Christ as yet to come, implicit faith sufficed for the greater part of the people:

Post peccatum autem fuit explicite creditum mysterium Christi non solum quantum ad incarnationem, sed etiam quantum ad passionem et resurrectionem, quibus humanum genus a peccato et morte liberatur. Aliter enim non praefigurassent Christi passionem quibusdam sacrificiis et ante legem et sub lege. Quorum quidem sacrificiorum significatum explicite maiores cognoscebant, minores autem sub velamine illorum sacrificiorum, credentes ea divinitus esse disposita de Christo venturo, quodammodo habebant velatam cognitionem ... Et ideo eo modo quo mysterium Christi ante Christum fuit quidem explicite creditum a maioribus, implicite autem et quasi obumbrate a minoribus, ita etiam et mysterium Trinitatis. Et ideo etiam post tempus gratiae divulgatae tenentur omnes ad explicite credendum mysterium Trinitatis. Et omnes qui renascuntur in Christo hoc adipiscuntur per invocationem Trinitatis, secundum illud Matth. ult., 'euntes, docete omnes gentes, baptizantes eos in nomine patris et filii et spiritus sancti. ${ }^{35}$

${ }^{35}$ But after sin, man believed explicitly in Christ, not only as to the incarnation, but also as to the passion and resurrection, whereby the human race is delivered from sin and death; for they would not, else, have foreshadowed Christ's passion by certain sacrifices both before and after the Law, the meaning of which sacrifices was known by the learned explicitly, while the simple folk, under the veil of those sacrifices, believed them to be ordained by God in reference to Christ's coming, and thus their knowledge was covered with a veil, so to speak ... wherefore just as, before Christ, the mystery of Christ was believed explicitly by the learned, but implicitly and under a veil, so to speak, by the simple, so too was it with the mystery of the Trinity. And consequently, when once grace had been revealed, all were bound to explicit faith in the mystery of the Trinity; and all who are born again in Christ, have this bestowed on them by the invocation of the Trinity, according to Matthew 28:19: "Going therefore teach ye all nations, baptizing them in the name of the Father, and of the Son and of the Holy Ghost." Dever. 14.11 resp.: 'Sed ante peccatum et post, omni tempore necessarium fuit a maioribus explicitam fidem de Trinitate habere; non autem a minoribus post peccatum usque ad tempus gratiae; ante peccatum enim forte talis distinctio non fuisset, ut quidam per alios erudirentur de fide. Et similiter etiam post peccatum usque ad tempus gratiae maiores tenebantur habere fidem de redemptore explicite; minores vero implicite, vel in fide patriarcharum et prophetarum, vel in divina providentia.' 
Significant as far as the second of them is concerned - those, that is to say, without the Law but sensitive to the providentiality of things is this passage, again from the Secunda secundae at 2.7 , where in reply to the objection that some of the gentiles appear on the testimony of the Areopagite to have been brought home irrespective of their ignorance of Christ and of the Christian mysteries, ${ }^{36}$ Thomas insists (a) that they were not, in fact, without oracular and other utterances testifying to the truth about to be revealed, and (b) that, though not party to Christian revelation precisely as such, they knew themselves in something approaching a sense of God's will to salvation:

Si qui tamen salvati fuerunt quibus revelatio non fuit facta, non fuerunt salvati absque fide mediatoris. Quia etsi non habuerunt fidem explicitam, habuerunt tamen fidem implicitam in divina providentia, credentes Deum esse liberatorem hominum secundum modos sibi placitos et secundum quod aliquibus veritatem cognoscentibus ipse revelasset ...

to which, for the sake of confirming his consistency hereabouts, we should add these lines from the De veritate on the comparability of the old Jews living as inferiores under the Law and of the gentiles living beyond the Law but possessed even so of an inkling of it:

gentiles non ponebantur ut instructores divinae fidei. Unde, quantumcumque essent sapientes sapientia saeculari, inter minores computandi sunt; et ideo sufficiebat eis habere fidem de redemptore implicite, vel in fide legis et prophetarum, vel etiam in ipsa divina providentia.

$(\text { De ver. } 14.11 \text { ad } 5)^{38}$

${ }^{36}$ ST IIa IIae.2.7 obj. 3: 'multi gentilium salutem adepti sunt per ministerium Angelorum, ut Dionysius dicit, IX cap. Cael. Hier. Sed gentiles non habuerunt fidem de Christo nec explicitam nec implicitam, ut videtur, quia nulla eis revelatio facta est. Ergo videtur quod credere explicite Christi mysterium non fuerit omnibus necessarium ad salutem.'

37 If, however, some were saved without receiving any revelation, they were not saved without faith in a mediator, for, though they did not believe in him explicitly, they did, nevertheless, have implicit faith through believing in divine providence, since they believed that God would deliver mankind in whatever way was pleasing to him, and according to the revelation of the Spirit to those who knew the truth ...

38 the gentiles were never deemed to be teachers in faith and divinity, whence, although they were wise in the secular way of being wise, they are to be counted as minores. It was therefore enough for them to have implicit faith in the redeemer or in the law or the prophets, or even in that same divine providence. 
True, as Thomas himself suggests, it is all somewhat hypothetical (the 'Si qui tamen salvati fuerunt quibus revelatio non fuit facta' of the Secunda secundae passage), but, given his commitment to belief in the Christ either as to come or else as already with us as the only sure way of salvation, the door is left ajar, Thomas's, as far as the pagans are concerned, being to this extent a generous sense of the matter. Persuaded as he is of the centrality of the Christ to every definitive account of God's dealings with man and thus of man's with God under the conditions of time and eternity, and thus, all other things being equal, of the indispensability of explicit faith as a condition of man's ultimate happiness, his, nonetheless, is a sense of the efficacy of implicit faith as a principle in casu of homecoming.

5. Now Dante, when it comes to those living outside the Christian dispensation but under the Old Law, is not too far removed, either in substance or in spirit, from Thomas, for though doing without the distinction between explicit and implicit faith decisive for the precise complexion of Thomas's position, he too is eager to bring home the Jewish patriarchs on the basis of their living in anticipation of the Christ to come; so, for example, on the threshold of the poem, the harrowing of hell passage of Inferno IV, at once inclusive and exclusive in spirit, inclusive as regards those living within the Old Law and exclusive as regards those living beyond it:

"Dimmi, maestro mio, dimmi, segnore", comincia' io per voler esser certo di quella fede che vince ogne errore:

"uscicci mai alcuno, o per suo merto o per altrui, che poi fosse beato?". E quei che 'ntese il mio parlar coverto, rispuose: "Io era nuovo in questo stato, quando ci vidi venire un possente, con segno di vittoria coronato.

Trasseci l'ombra del primo parente, d'Abèl suo figlio e quella di Noè, di Moïsè legista e ubidente;

Abraàm patrïarca e Davìd re, Israèl con lo padre e co' suoi nati e con Rachele, per cui tanto fé,

e altri molti, e feceli beati. E vo' che sappi che, dinanzi ad essi, spiriti umani non eran salvati".

$(\text { Inf. IV.46-63) })^{39}$

39 “Tell me, master, tell me, sir", I began, wishing to be assured of the faith that conquers 
while further on in the poem, the Hebrew women passage of Paradiso XXXII, where, as Dante himself puts it (the 'secondo lo sguardo che fée / la fede in Cristo' of lines 19-20), it is a question of directionality, of those looking forward rather than backward upon the Christ event as the pivotal point of world-historical understanding:

E dal settimo grado in giù, sì come infino ad esso, succedono Ebree, dirimendo del fior tutte le chiome;

perché, secondo lo sguardo che fée la fede in Cristo, queste sono il muro a che si parton le sacre scalee.

Da questa parte onde 'l fiore è maturo di tutte le sue foglie, sono assisi quei che credettero in Cristo venturo;

da l'altra parte onde sono intercisi di vòti i semicirculi, si stanno quei ch'a Cristo venuto ebber li visi.

(Par. XXXII.16-27) $)^{40}$

But when it comes to those living before and beyond the Old and New Law he is not so sure, for these, though sensitive to the providentiality of it all, were nonetheless bereft of the word which, quickened as it is by the Spirit, alone brings a man to the fullness of faith and the blessedness thereof. And this, for Dante, makes all the difference, for while for Thomas faith and the blessedness thereof are the product of a movement of grace notionally and substantially independent of their external occasions, ${ }^{41}$ for

every error, did ever anyone go forth from here, either by his own or by another's merit, who afterwards was blessed?" And he, who understood my covert speech, replied, "I was new in this condition when I saw a mighty one come here, crowned with sign of victory. He took hence the shade of our first parent, Abel his son, and Noah, and Moses, obedient giver of laws, Abraham the patriarch and David the king, Israel with his father and his children and with Rachel, for whom he did so much, and many others; and he made them blessed. And I would have you know that before these no human souls were saved."

40 And from the seventh row downwards, even as down to it, Hebrew women follow in succession, dividing all the trees of the flower; because, according to the look which their faith turned to Christ, these are the wall by which the sacred stairway is divided. On this side, wherein the flower is mature in all its petals, are seated those who believed in Christ yet to come. On the other side, where the half-circles are broken by vacant places, sit those who turned their faces towards Christ already come.

${ }^{41}$ ST IIa IIae 6.1 resp.: 'Quantum vero ... ad assensum hominis in ea quae sunt fidei, potest considerari duplex causa. Una quidem exterius inducens, sicut miraculum visum, vel persuasio hominis inducentis ad fidem. Quorum neutrum est sufficiens causa, videntium enim unum et idem miraculum, et audientium eandem praedicationem, quidam credunt 
Dante the external occasions of faith, including above all Scripture as the living word of God, constitute in themselves a channel of grace, herein lying their indispensability to a coming home of the individual to his proper happiness; so, for example, on the power of Scripture in and through itself - irrespective, that is to say of any movement of the Spirit other than that by which it is itself irradiated - to persuasion, the 'silogismo che la m'ha conchiusa' sequence of Paradiso XXIV.91-96:

E io: "La larga ploia

de lo Spirito Santo, ch'è diffusa

in su le vecchie e 'n su le nuove cuoia,

è silogismo che la m'ha conchiusa

acutamente sì, che 'nverso d'ella

ogne dimostrazion mi pare ottusa." ${ }^{2}$

the 'e a tal creder non ho io pur prove / fisice e metafisice' sequence of the same canto at lines 130-38:

$\mathrm{E}$ io rispondo: Io credo in uno Dio solo ed etterno, che tutto 'l ciel move, non moto, con amore e con disio;

e a tal creder non ho io pur prove

fisice e metafisice, ma dalmi

anche la verità che quinci piove

per Moïsè, per profeti e per salmi,

per l'Evangelio e per voi che scriveste

poi che l'ardente Spirto vi fé almi. ${ }^{43}$

and the 'Avete il novo e 'l vecchio Testamento' passage of Paradiso V.73-78:

et quidam non credunt. Et ideo oportet ponere aliam causam interiorem, quae movet hominem interius ad assentiendum his quae sunt fidei. Hanc autem causam Pelagiani ponebant solum liberum arbitrium hominis, et propter hoc dicebant quod initium fidei est ex nobis, inquantum scilicet ex nobis est quod parati sumus ad assentiendum his quae sunt fidei; sed consummatio fidei est a Deo, per quem nobis proponuntur ea quae credere debemus. Sed hoc est falsum. Quia cum homo, assentiendo his quae sunt fidei, elevetur supra naturam suam, oportet quod hoc insit ei ex supernaturali principio interius movente, quod est Deus. Et ideo fides quantum ad assensum, qui est principalis actus fidei, est a Deo interius movente per gratiam.'

42 And I: "The plenteous rain of the Holy Spirit which is poured over the old and new parchments is a syllogism that has proved it to me so acutely that, in comparison with this, every demonstration seems obtuse to me."

43 And I reply: I believe in one God, sole and eternal, who, unmoved, moves all the heavens with love and with desire; and for this belief I have not only proofs physical and metaphysical, but it is given to me also in the truth that rains down hence through Moses and the prophets and the psalms, through the gospel, and through you who wrote when the fiery Spirit made you holy. 
Siate, Cristiani, a muovervi più gravi:

non siate come penna ad ogne vento, e non crediate ch'ogne acqua vi lavi.

Avete il novo e 'l vecchio Testamento,

e 'l pastor de la Chiesa che vi guida;

questo vi basti a vostro salvamento. ${ }^{44}$

each alike secure in its sense of Scripture, along with the inspired teaching of the Church (the 'e 'l pastor de la Chiesa che vi guida' of the Paradiso V passage), as salvifically sufficient. Throughout, then, the pattern is the same. Dispensing with the notion of grace as dispositive in respect of faith as a property of the spirit (a notion which, especially when taken in conjunction with that of implicit faith, leaves considerable room for manoeuver), Dante opts instead for the encounter pure and simple as a means of grace and principle of salvation, an option, however, at once making for the exclusion of whole tracts of humanity from the feast of the Lamb. And it is precisely this - the melancholy of a position not entirely innocent of effrontery in respect of the wideness of God's mercy - that urged him to rethink the issue here with a view to resolving it at the highest conceivable level, in terms, that is to say, less of the revelatory instant in all its historical contingency, than of the love and thus of the love-susceptibility of One whose being $i$ his loving. It is, in other words, the sadness of a soteriology making only for repudiation as its point of arrival, that, in a moment of exhilaration, encouraged him, indeed compelled him, to revise the whole question of ultimate being and becoming in turns of the willingness of God (a) to accommodate all those who in good faith plead the cause of the righteous spirits of antiquity (the case of Trajan), and (b) to grace those who, though unChristed and unchurched, nevertheless lived or live still according to their lights (the case of Rhipeus). First, then, in the order of exposition comes the predicament of the good man and true, who, though bereft of Christ through no fault of his own, lives even so a just and honourable life. Where, the pilgrim protagonist wonders, is the justice which condemns him?:

Assai t'è mo aperta la latebra che t'ascondeva la giustizia viva, di che facei question cotanto crebra; ché tu dicevi: "Un uom nasce a la riva de l'Indo, e quivi non è chi ragioni di Cristo né chi legga né chi scriva; e tutti suoi voleri e atti buoni

${ }^{44}$ Be graver, you Christians, in moving. Be not like a feather to every wind, and think not that every water may cleanse you. You have the New Testament and the Old, and the Shepherd of the Church to guide you. Let this suffice for your salvation. 
sono, quanto ragione umana vede, sanza peccato in vita o in sermoni.

Muore non battezzato e sanza fede: ov' è questa giustizia che 'l condanna? ov' è la colpa sua, se ei non crede?".

$(\text { Par. XIX.67-78) })^{45}$

The answer, delivered by the celestial eagle, comes in two parts, the first of which, taken alone, is no answer at all, merely a preliminary admonition: let no one, the eagle says, jump to conclusions, for all justice is grounded in the righteousness of God, which, forever consistent with the goodness of which it is but the outshining, informs steadily - if, as far as man is concerned, inscrutably - his every decree:

Or tu chi se', che vuo' sedere a scranna, per giudicar di lungi mille miglia con la veduta corta d'una spanna?

Certo a colui che meco s'assottiglia, se la Scrittura sovra voi non fosse, da dubitar sarebbe a maraviglia.

Oh terreni animali! oh menti grosse! La prima volontà, ch'è da sé buona, da sé, ch’è sommo ben, mai non si mosse.

Cotanto è giusto quanto a lei consuona: nullo creato bene a sé la tira, ma essa, radïando, lui cagiona.

(Par. XIX.79-90) $)^{46}$

${ }^{45}$ Now is laid well open to you the hiding place which concealed from you the living justice concerning which you have made question so incessantly. For you said, "A man is born on the banks of the Indus, and none is there to speak, or read, or write of Christ, and all his wishes and acts are good, so far as human reason sees, without sin in life or in speech. He dies unbaptized, and without faith. Where is this justice which condemns him? Where is his sin if he does not believe?"

${ }^{46}$ Now who are you who would sit upon the seat to judge at a thousand miles away with the short sight that carries but a span? Assuredly, for him who subtilizes with me, if the Scriptures were not set over you, there would be marvelous occasion for questioning. $O$ earthly animals! O gross minds! The primal will, which of itself is good, has never moved from itself, which is the supreme good. All is just that accords with it; no created good draws it to itself, but it, raying forth, is the cause of it. Mon. II.ii.4-5: 'Ex hiis iam liquet quod ius, cum sit bonum, per prius in mente Dei est; et, cum omne quod in mente Dei est sit Deus, iuxta illud "Quod factum est in ipso vita erat", et Deus maxime se ipsum velit, sequitur quod ius a Deo, prout in eo est, sit volitum. Et cum voluntas et volitum in Deo sit idem, sequitur ulterius quod divina voluntas sit ipsum ius. Et iterum ex hoc sequitur quod ius in rebus nichil est aliud quam similitudo divine voluntatis; unde fit quod quicquid divine voluntati non consonat, ipsum ius esse non possit, et quicquid divine voluntati est consonum, ius ipsum sit.' 
- an emphasis straightaway confirmed in the 'Roteando cantava' tercet beginning at line 97 of the same canto:

Roteando cantava, e dicea: "Quali

son le mie note a te, che non le 'ntendi, tal è il giudicio etterno a voi mortali". ${ }^{47}$

But, then, from out of the stillness (the 'Poi si quetaro quei lucenti incendi / de lo Spirito Santo ...' of XIX.100-101) ${ }^{48}$ comes the reply proper to Dante's question, a reply nicely attentive once again to its periodization, its step-by-step unfolding. First, then, comes the Johannine moment of the argument to the effect that no one comes to the Father other than by way of the Son as crucified (the 'A questo regno / non salì mai chi non credette 'n Cristo, / né pria né poi ch'el si chiavasse al legno' of lines 103105), ${ }^{49}$ and then the Matthean moment to the effect that many of those crying 'Christ! Christ!' will be turned away as strangers to him (the 'Ma vedi: molti gridan "Cristo, Cristo!", / che saranno in giudicio assai men prope / a lui, che tal che non conosce Cristo' of lines 106-108), ${ }^{50}$ the latter, however, serving merely to reinforce the pathos everywhere generated by the spectacle of those living out the synderectic substance of their being but even so far off. And with this - this recognizably Pauline sense of the claim set up by those not so much proclaiming the law as bearing it inscribed on their hearts ${ }^{51}$ - we come to the nub of the matter, to Dante's

47 Wheeling it sang and said, "As are my notes to you who understand them not, such is the eternal judgement to you mortals".

48 After those glowing flames of the Holy Spirit became quiet ...

49 To this realm none ever rose who believed not in Christ, either before or after he was nailed to the tree. John 14:6: 'Dicit ei Jesus: ego sum via et veritas et vita; nemo venit ad Patrem nisi per me.'

${ }^{50}$ But behold, many cry Christ, Christ, who, at the judgement, shall be far less near to him than he who knows not Christ. Matt. 7:21-23: 'Non omnis qui dicit mihi Domine, Domine intrabit in regnum cœlorum, sed qui facit voluntatem Patris mei, qui in cœlis est, ipse intrabit in regnum cœlorum. Multi dicent mihi in illa die: Domine, Domine, nonne in nomine tuo prophetavimus, et in nomine tuo dæmonia ejecimus, et in nomine tuo virtutes multas fecimus? Et tunc confitebor illis, quia nunquam novi vos, discedite a me, qui operamini iniquitatem.'

${ }^{51}$ Romans 2:14-15: 'Cum enim Gentes, quae legem non habent, naturaliter ea quae legis sunt, faciunt, ejusmodi legem non habentes, ipsi sibi sunt lex. Qui ostendunt opus legis scriptum in cordibus suis, testimonium reddente illis conscientia ipsorum et inter se invicem cogitationum accusantium, aut etiam defendentium, in die, cum judicabit Deus occulta hominum, secundum evangelium meum per Jesum Christum.' P. S. Hawkins, 'Dante, St Paul, and the Letter to the Romans', in Medieval Readings in Romans, ed. W. S. Campbell, P. S. Hawkins and B. D. Schildgen (Edinburgh and New York: Continuum and T. \& T. Clark, 2007), pp. 115-31. More generally, J. A. Mazzeo, 'Dante and the Pauline Modes of Vision', in Structure and Thought in the 'Paradiso' (Ithaca, N.Y.: Cornell University 
account, not simply of the susceptibility, but of the vulnerability of God as seeing and delighting in the good works of the pagan spirit. Startled, then, by the presence in paradise of Trajan and Rhipeus as innocent of Christ and clergy, but invited by the eagle of righteousness to think through the deep reasons of it all, the pilgrim poet is at last initiated in an act of understanding, in a sense of God's readiness, not only to love, but to be won over by love, herein lying the triumph of love over lovelessness:

\author{
Regnum celorum vïolenza pate \\ da caldo amore e da viva speranza, \\ che vince la divina volontate: \\ non a guisa che l'omo a l'om sobranza, \\ ma vince lei perché vuole esser vinta, \\ e, vinta, vince con sua beninanza.
}

$(\text { Par. XX.94-99) })^{52}$

Press, 1958; reprint New York: Greenwood, 1968), pp. 84-110; G. Petrocchi, 'San Paolo in Dante', in G. Barblan (ed.), Dante e la Bibbia. Attidel Convegno internazionale promosso da Biblia, Florence, 26-28 settembre 1986 (Florence: Olschki, 1988), pp. 235-48 (subsequently in La selva del protonotario. Nuovi studidanteschi (Naples: Morano, 1988), pp. 65-82); R. Hollander, Dante and Paul's 'Five Words with Understanding' (Binghampton, N.Y.: Center for Medieval and Early Renaissance Studies, 1992); G. Di Scipio, The Presence of Pauline Thought in the Works of Dante (Lewiston, Queenston and Lampeter: Edwin Mellen, 1995).

${ }^{52}$ Regnum celorum suffers violence from fervent love and from living hope which vanquishes the divine will; not as man overcomes man, but vanquishes it because it wills to be vanquished, and, vanquished, vanquishes with its own benignity. G. Cannavò, Regnum celorum vïolenza pate. Dante e la salvezza dell'umanità. Letture Dantesche Gübilari, Vicenza, ottobre 1999 - giugno 2000 (Montella (Avellino): Accademia Vivarium Novum, 2002), with, at pp. 193-203, A. M. Chiavacci Leonardi, 'La salvezza degli infedeli: il canto XX del Paradiso' (subsequently in Le bianche stole. Saggi sul Paradiso di Dante (Florence: Sismel, 2009), pp. 97-112). Also, F. Ruffini, 'Dante e il problema della salvezza degli infedeli', Studidanteschi 14 (1930), 79-92; B. Quilici, Il destino dell'infidele virtuoso nel pensiero di Dante (Florence: Ariani, 1936); T. O'H. Hahn, 'I "gentili” e "un uom nasce a la riva / de l'Indo” (Par. XIX, vv.70 sqq.)', L'Alighieri. Rassegna bibliografica Jantesca 18 (1977), 2, 3-8; R. Morghen, 'Dante tra l'“umano” e la storia della salvezza', in LiAlighieri. Rassegna bibliografica Jantesca 21 (1980), 1, 18-30; N. Iliescu, 'Will Virgil be saved?', Mediaevalia 12 (1986), 93-114 and as 'Sarà salvo Virgilio?' in Dante. Summa medievalis. Proceedings of the Symposium of the Center for Italian Studies, SUNY Stony Brook, ed. C. Franco and L. Morgan (Stony Brook, N.Y.: Forum Italicum, 1995), pp. 112-33; M. Allan, 'Does Dante hope for Vergil's Salvation?', Modern Language Notes 104 (1989), 193-205; M. Picone, 'La "viva speranza" di Dante e il problema della salvezza dei pagani virtuosi. Una lettura di Paradiso 20', Quaderni di Italianistica 10 (1989), 1-2, 251-68 ; idem, 'Auctoritas classica e salvezza cristiana: una lettura tipologica di Purgatorio XXII', in Studi in memoria di Giorgio Varanini (Pisa: Giardini, 1992), vol. I (Dal Duecento al Quattrocento), pp. 379-95; T. Barolini, 'Q: Does Dante hope for Vergil's Salvation?', Modern Language Notes 105 (1990), 1, 138-44 and 147-49 (and in Dante and the Origins of Italian Literary Culture (New York: Fordham University Press, 2006), pp. 151-57); B. D. Schildgen, 'Dante and the Indus', Dante 
Taking as his core text the difficult saying of Christ in Matthew 11:12 to the effect that 'ever since the coming of John the Baptist the kingdom of heaven has been subject to violence and violent men are seizing it ${ }^{\prime},{ }^{3}$ Dante fashions from it a notion reaching as far into the essential nature of the Godhead as it is possible for man to go, a notion which, transcending as it does the customary голо of God-discourse relative to his impassivity and unmoveability, settles on his love-responsiveness, on his willingness, where love is concerned, to reply in kind. Now here, clearly, we have to be careful, for tempting as it is to see in this a breaking of the mould in the area of election theology, we need to note that neither the 'viva speranza' nor the 'caldo amore' of which the eagle speaks originates with the beneficiary of that love, the former, the lively hope, proceeding from the prayers of the supplicant spirit, and the latter from the storehouse of God's own graciousness:

D'i corpi suoi non uscir, come credi, Gentili, ma Cristiani, in ferma fede

Studies 111 (1993), 177-93; eadem, 'Dante's Utopian Political Vision, the Roman Empire, and the Salvation of Pagans', Annalid'Italianistica 19 (2001), 51-69; G. Muresu, 'Le "vie" della redenzione (Paradiso VII)', Rassegna della letteratura italiana, ser. 8, 98 (1994), 1-2, 5-19; N. Cacciaglia, "Per fede e per opere" (una lettura del tema della salvezza nella Divina Commedia)', in Critica Letteraria 30 (2002), 2-3, 265-74 (also in Annalidell'Università per Stranieri di Perugia 29 (2002), 123-131); B. Martinelli, 'Canto XIX', in Lectura Dantio Turicensis. Paradiso, ed. G. Güntert and M. Picone (Florence: Cesati, 2002), pp. 281-305 (revised with the title 'La fede in Cristo. Dante e il problema della salvezza (Paradiso XIX)', Rivista di Letteratura Italiana 20 (2002), 2, 11-39, and in Dante. L'altro viaggio" (Pisa: Giardini, 2007), pp. 289-319); G. Inglese, 'Il destino dei non credenti. Lettura di Paradiso XIX', La Cultura. Rivista trimestrale di filosofia letteratura e storia 42 (2004), 2, 31529; A. Lanza, 'Giustizia divina e salvezza dei "senza fede", in Dante eterodosso (Bergamo: Moretti Honegger, 2004), pp. 113-24; C. O'Connell Baur, Dante's Hermeneutics of Salvation. Passages to Freedom in the Divine Comedy (Toronto, Buffalo and London: University of Toronto Press, 2007). More generally, S. Harent, 'Infidèles, Salut des', Dictionnaire de Théologie Catholique, 15 vols, ed. P. Moraux et al. (Paris: Letouzey et Ané, 1909-46), vol. 7, ii, cols 1276-1930; L. Capéran, Le Problème du salut des infidèles, 2 vols, revised edn (Toulouse: Grand Séminaire, 1934); T. P. Dunning, 'Langland and the Salvation of the Heathen', Medium Aevum 12 (1943), 45-54; M. Frezza, Il problema della salvezza dei pagani (da Abelardo al Seicento) (Naples: Fiorentino, 1962); R. V. Turner, “Descendit ad Inferos". Medieval Views on Christ's descent into Hell and the Salvation of the Ancient Just', Journal of the History of Ideas 27 (1966), 173-94; C. L. Vitto, The Virtuous Pagan in Middle English Literature. Transactions of The American Philosophical Society 79, part 5 (Philadelphia: The American Philosophical Society, 1989), pp. 36-49; N. Watson, 'Visions of Inclusion. Universal Salvation and Vernacular Theology in Pre-Reformation England', Journal of Medieval and Early Modern Studies 27 (1997), 145-88. On the cases of Trajan and Rhipeus, G. Whatley, 'The Uses of Hagiography: the Legend of Pope Gregory and the Emperor Trajan in the Middle Ages', Viator 15 (1984), 25-63.

53 'a diebus autem Joannis Baptistae usque nunc, regnum cælorum vim patitur, et violenti rapiunt illud'; Luke 16:16: 'Lex et prophetae, usque ad Joannem; ex eo regnum Dei evangelizatur, et omnis in illud vim facit.' Translation NEB. 
quel d'i passuri e quel d'i passi piedi.

Ché l'una de lo 'nferno, u' non si riede già mai a buon voler, tornò a l'ossa; e ciò di viva spene fu mercede:

di viva spene, che mise la possa ne' prieghi fatti a Dio per suscitarla, sì che potesse sua voglia esser mossa.

L'anima glorïosa onde si parla, tornata ne la carne, in che fu poco, credette in lui che potëa aiutarla;

e credendo s'accese in tanto foco di vero amor, ch'a la morte seconda fu degna di venire a questo gioco.

L'altra, per grazia che da sì profonda fontana stilla, che mai creatura non pinse l'occhio infino a la prima onda, tutto suo amor là giù pose a drittura: per che, di grazia in grazia, Dio li aperse l'occhio a la nostra redenzion futura; ond' ei credette in quella, e non sofferse $\mathrm{da}$ indi il puzzo più del paganesmo; e riprendiene le genti perverse.

$(\text { Par. XX.103-26) })^{54}$

54 They came forth from their bodies not as you think, gentiles, but Christians, with firm faith, the one in the feet that were to suffer, the other in the feet that had suffered. For the one came back to his bones from hell, where none ever returns to right will; and this was the reward of living hope, of living hope that gave power to the prayers made to God to raise him up, that it might be possible for his will to be moved. The glorious soul I tell of, having returned to the flesh for a short time, believed in him that was able to help him; and, believing, was kindled to such a fire of true love that on his second death he was worthy to come to this rejoicing. The other, through grace that wells from a fountain so deep that never did creature thrust eye down to its first wave, set all his love below on righteousness; wherefore, from grace to grace, God opened his eye to our future redemption, so that he believed in it, and therefore endured not the stench of paganism, and reproved the perverse peoples for it. On Dante and the virtuous pagans (in addition to commentaries and lecturae on Inferno IV), G. Rizzo, 'Dante and the Virtuous Pagans', in Dante Symposium in Commemoration of the 700th Anniversary of the Poet's Birth (1265-1965), ed. W. De Sua and G. Rizzo (Chapel Hill: University of North Carolina Press, 1965), pp. 115-40; K. Foster, O.P., 'The Two Dantes (III). The Pagans and Grace', in The Two Dantes and Other Studies (London: Darton, Longman and Todd, 1977), pp. 220-53 (also, in the same volume, pp. 137-55, 'The Son's Eagle: Paradiso XIX'); D. Thompson, 'Dante's Virtuous Romans', Dante Studies 96 (1978), 145-62; H.A. Mason, 'A Journey through Hell: Dante's Inferno Revisited. Virtuous pagans - "gente di molto valore”. Canto IV', The Cambridge Quarterly 16 (1987), 3, 187-211; M. Picone, 'La "viva speranza" di Dante e il problema della salvezza dei pagani virtuosi. Una lettura di Paradiso 20' (note 52 
There can, then, be no inferring from this passage a theology of election unconstrained by the customary contents of Christian consciousness, a theology of election, that is to say, countenancing the dispensability of grace, and above all of the grace made available to us in Christ, to any ultimate homecoming of the soul. At the same time something stirs in the depths, a sense of God's concern, not simply for those seated at his table, but for the stranger at the gate, and for his status too as a guest. Something of the kind, at any rate, would seem to be the substance of Dante's final reflection in this canto, of his sense of the wind as blowing where it listeth and of this as its sweetness:
O predestinazion, quanto remota
è la radice tua da quelli aspetti
che la prima cagion non veggion tota!
E voi, mortali, tenetevi stretti
a giudicar: ché noi, che Dio vedemo,
non conosciamo ancor tutti li eletti;
ed ènne dolce così fatto scemo,
perché il ben nostro in questo ben s'affina,
che quel che vole Iddio, e noi volemo.

(ibid. XX.130-38) $)^{55}$

above); C. L. Vitto, 'The Virtuous Pagan in Legend and in Dante', in The Virtuous Pagan in Middle English Literature (note 52 above); M. L. Colish, 'The Virtuous Pagan: Dante and the Christian Tradition', in The Unbounded Community. Papers in Christian Ecumenism in Honor of Jaroslav Pelikan, ed. W. Caferro and D. G. Fisher (New York: Garland, 1996), pp. 43-91; G. Inglese, 'Il destino dei non credenti. Lettura di Paradiso XIX', La Cultura. Rivista trimestrale di filosofia letteratura estoria (note 52 above). On Virgil (Dante's Virgil) in particular, and in addition to the Enciclopedia dantesca ad voc. (Rome: Istituto dell'Enciclopedia Italiana, 1970-78), vol. 5, pp. 1030-44; E. Auerbach, Dante Poet of the Secular World, trans. R. Manheim (Chicago and London: Chicago University Press, 1961 and reprints; originally 1929), with 'Dante und Virgil', Das Humanistiches Gymnasium 42 (1931), 136-44; D.Consoli, Significato del Virgilio dantesco (Florence: Le Monnier, 1967); R. Hollander, Il Virgilio dantesco: tragedia nella 'Commedia' (Florence: Olschki, 1983); T. Barolini, Dante's Poets. Textuality and Truth in the 'Comedy' (Princeton NJ: Princeton University Press, 1984). More generally, D. Comparetti, Vergil in the Midde Ages, trans. E. F. M. Benecke (Princeton, N.J.: Princeton University Press, 1997; original Italian 1872). On the Dantean limbo, G. Busnelli, 'La colpa del "non fare” degli infedeli negativi', Studi danteschi 23 (1938), 79-97; G. Padoan, 'Il limbo dantesco', Lettere italiane 21 (1969), 369-88 (and in Il pio Enea, l'empio Ulisse (Ravenna: Longo, 1977), pp. 103-24); K. Foster, O.P., 'The Two Dantes (I). Limbo and Implicit Faith', in the Two Dantes (above), pp. 156-89; A. A. Iannucci, 'Limbo: the Emptiness of Time', Studidanteschi 52 (1979-80), 69-128.

${ }_{55} \mathrm{O}$ predestination, how remote is thy root from the vision of those who see not the first cause entire! And you mortals, keep yourselves restrained in judging; for we who see God, know not yet all the elect. And to us such defect is sweet, because our good in this good is refined, that what God wills we also will. 
To rest in God, in other words, is to rest in the sweet understanding that, however he chooses to resolve it all, his will be a resolution in love, understanding to this effect serving but to refine still further the joy of the elect.

Love-magnanimity, therefore, and love-responsiveness, these are the twin emphases of Dante's mature meditation in the areas of atonement and of election theology: the kind of love-magnanimity whereby, in the midst of his destitution, man is freshly empowered as man and the kind of love-responsiveness whereby, consubstantial and co-extensive with his own loving, God cannot but reply in kind to a movement of love wherever he sees it. Good theology? Most certainly. For this is theology which, jealous of its credentials and communicability, is forever on the point of being undone by its own agapeic substance, its fundamental inequality to the business in hand. 